\title{
Real-Time Monitoring and Assessment of Thermal and Toxicological Risk Associated with Fire Retardant Textiles in a Full-Size Simulation of an Engulfment Flash Fire
}

\author{
Christopher E. Mackay* and Stephanie N. Vivanco, Amec Foster Wheeler \\ Environment and Infrastructure, 122 Innovation Dr., Irvine, CA 92617, \\ $U S A$
}

Timothy E. Reinhardt, Amec Foster Wheeler Environment and Infrastructure, One Union Square, Seattle, WA 98101, USA

Steve McClure, Amec Foster Wheeler Environment and Infrastructure, 160

Traders Blvd. E. Suite 110, Mississauga, ON L4Z 3K7, Canada

Jeff Vercellone, Kaneka Corporation, 546 Fifth Ave, New York, NY 10036, USA

Received: 27 August 2014/Accepted: 7 January 2015

Abstract. A comparative risk assessment was performed on nine commercial flameretardant materials in garments intended for general occupational use. The assessment evaluated the relative hazards associated with combustion gases during a full engulfment flash fire in accordance with ASTM F1930 and ISO 13506. The materials in the form of whole body coveralls were subjected to propane-fired flash conditions of $84 \mathrm{~kW} / \mathrm{m}^{2}$ for a duration of 3 or $4 \mathrm{~s}$. Combustion gas composition and concentrations were measured in the breathing zone of the test manikin in real time by Fourier transform infrared spectrophotometry as was the gas temperature. Results were used to parameterize thermokinetic and toxicokinetic models used to predict both injury and gas exposure. The results indicated that an individual maintaining regular ventilation would receive third degree burns to the upper airway at both durations. In the case of the $4 \mathrm{~s}$ burn, third degree injury would reach the larynx, resulting in involuntary apnea, in about $12 \mathrm{~s}$ post-ignition. Combustion gas production was high, but of very short duration meaning that exposure was limited by the receptor's ventilation cycle. Hazards to parties giving aid were limited by rapid declines in combustion gas production and temperature that returned to background concentrations within about $60 \mathrm{~s}$ post-ignition. Comparisons made between materials indicated the marked presence of hydrogen chloride, cyanide, and nitrogen dioxide production for the fire retardant (FR) modacrylic blends; cyanide, nitrogen dioxide, and sulfur dioxide for FR cotton; and sulfur dioxide for the FR rayon blends. None of the gas exposures were found to represent a significant risk to health or impedance to survival or escape to the individual wearing the garment, or other persons that may come to their assistance. Particulate antimony was detected in the technologies that use it as a

\footnotetext{
* Correspondence should be addressed to: Christopher E. Mackay, E-mail: chris.mackay@amecfw.com
} 
fire retardant, but at concentrations well below anything that could be considered hazardous.

Keywords: Fire retardant textiles, Modacrylic, Cotton, Flash fire, Toxicology, Thermokinetic, Toxicokinetic, Risk assessment

\section{Introduction}

Concern has been voiced in the fire protection industry that protective textiles composed of synthetic fibers may represent a health hazard as the result of the inhalation of gaseous combustion products. Several bench top studies have looked at combustion gas generation from small areas of textiles and have reported increased concentrations of hydrogen chloride, hydrogen cyanide, and other combustion constituents coming from flame-retardant products containing modacrylic and nylon fibers [1, 2]. Some authors have gone on from these bench top results and suggested that the rates of combustion gas production represent an imminent health hazard $[3,4]$. These projections are usually based on arithmetic scaling and comparisons to occupational or relatively long duration toxicity standards and guidances.

Standard bench top methods have been developed to bioassay the toxicity of combustion emissions using rodents [5,6]. All involve the generation of combustion gases through the heating of sample materials, and then venting the gases into remote inhalation enclosures. While providing a better prediction of biological response, it still represents a very artificial exposure situation because (1) the rat or mouse receptor has been removed from the actual combustion process; and (2) because of the architecture of their upper airway, rodents make poor experimental models for tracheal and pharyngeal exposure situations for humans [7].

The exposure of an individual to a full engulfment flash fire event is a very rapid and kinetic process. While there is no standard fire, the standardized method used to test fire retardant textiles from full engulfment flash fires is a thermal input of $84 \mathrm{~kW} / \mathrm{m}^{2}$ for a variable length of time [8,9]. The probability of an individual without respiratory and insulating protection surviving such conditions for any more than 3-4 s is exceedingly low. Because of the high intensity and short survivability duration, the process never reaches any kind of equilibrium state. It includes a number of dynamic processes involving the heat source, the reaction of the textile to the increased heat flux, the reactions involved in the oxidation of the textiles, and changes in air movement as the result of heating and the introduction of gases of varying densities and buoyancies. Superimposed upon these events is the human with its specific geometry, biphasic ventilation, instantaneous reactions to events, and its own systematic reactivity and susceptibility to chemical exposure and extreme thermal inputs.

The purpose of this study was to address the issues as to whether gaseous and/ or particulate combustion products represent a potential health risk to general occupational individuals exposed to a flash fire event while wearing fire resistant 
textiles. Using a full-sized simulator, nine types of commercial fire retardant textiles as full overalls were exposed to propane-fired flash conditions of $84 \mathrm{~kW} / \mathrm{m}^{2}$ for either 3 or $4 \mathrm{~s}$. During and immediately after the event, gas temperature and composition was measured in the breathing zone in real time. The results were used to parameterize thermokinetic and toxicokinetic models to determine both exposure and probability of adverse health impact to an individual who endures such an event as well as those who may come immediately to his/her aid.

\section{Materials and Methods}

\subsection{Experimental Design and Measurement Systems}

Nine fire retardant textiles were tested for gas emissions in a full-sized flash fire simulation. Materials were in the form of standardized work coveralls used for general occupational protection and not specific for firefighters. The textiles tested were all commercially available and employed Protex ${ }^{\circledR}$ modacrylic, Proban $\mathrm{CC}^{\mathrm{TM}}$ cotton, and flame-resistant rayon used in army combat uniform technologies (Table 1).

The fire exposure testing was performed during the week of October 7, 2013. Garments were pre-conditioned as required and then exposed to a simulated engulfment flash fire consistent with the requirements of ASTM 1930 [8]. The fullsize fire exposure was performed in a six by six by eight foot enclosure open at the base and top to allow combustion emissions to mix with ambient air and flow vertically (Figure 1). The heat flux was provided by eight propane-fired jets aimed at approximately ankle and hip height that introduced flames from nozzles positioned at the left and right, front and rear. The system was calibrated to provide an average thermal input of $84 \pm 5 \% \mathrm{~kW} / \mathrm{m}^{2}\left(2 \mathrm{cal} / \mathrm{cm}^{2}\right)$ as required under ASTM 1930, Section 10 (Table 2). The incident heat flux was determined from the response of 122 copper calorimeter sensors about the manikin. The sensors were calibrated to an NIST-traceable reference Schmidt-Boelter calorimeter to minimize

\section{Table 1}

\section{List and Identification of Materials Tested in This Study}

Composition

\begin{tabular}{ll}
\hline A & Low Protex ${ }^{\circledR}$ Modacrylic Blend \\
B & Medium Protex ${ }^{\circledR}$ Modacrylic Blend \\
C & Medium Protex ${ }^{\circledR}$ Modacrylic Blend \\
D & High Protex ${ }^{\circledR}$ Modacrylic Blend \\
E & High Protex ${ }^{\circledR}$ Modacrylic Blend \\
F & $100 \%$ Protex ${ }^{\circledR}$ Modacrylic \\
G & FR Treated Cotton/Nylon Blend \\
H & FR Treated Cotton \\
I & FR Rayon Blend \\
\hline
\end{tabular}




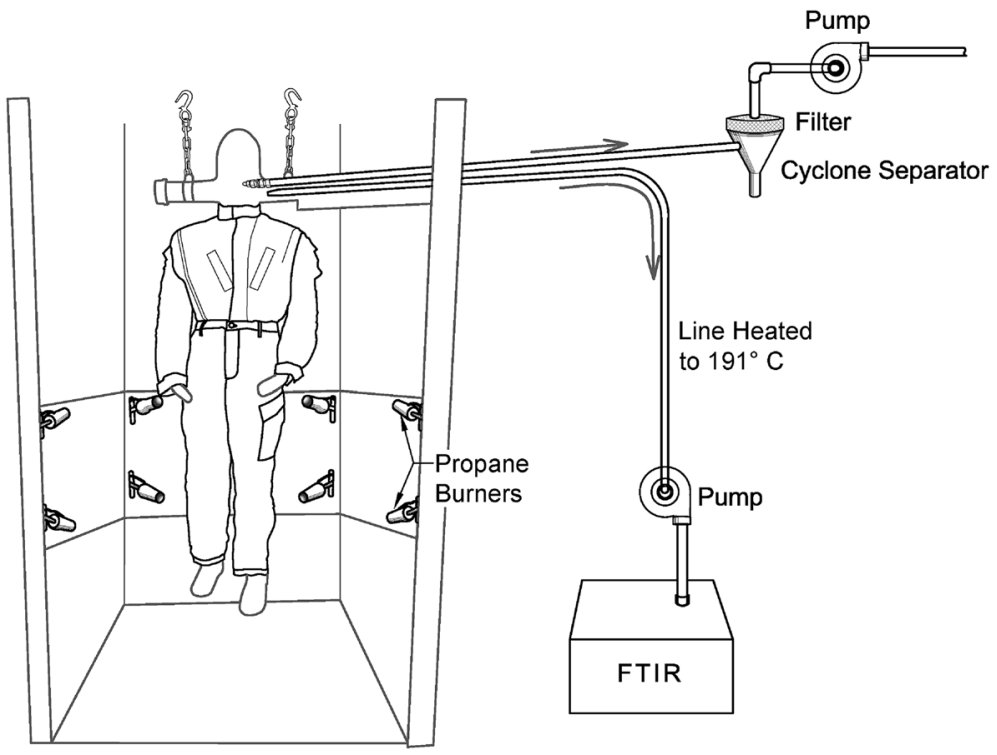

Figure 1. Diagram of the test chamber used in the flash fire tests. Thermal flux was provided by eight propane burners aimed at the waist and ankle. Air was sampled from the breathing zone where it was passed either through a heated line to the in-line FTIR, or to the proximal cyclone separator for respirable particulate collection.

\section{Table 2 \\ Calorimeter Response in the Calibration of the Manikin Heat Flux in Flash Fire Exposure}

\begin{tabular}{lcc}
\hline Body region & Calorimeter count per region & Heat flux mean $(\mathrm{sd}) \mathrm{Cal} / \mathrm{cm}^{2}$ \\
\hline Head & 8 & $2.182(0.326)$ \\
Back & 21 & $2.120(0.527)$ \\
Chest & 28 & $1.942(0.334)$ \\
Left arm & 10 & $1.806(0.283)$ \\
Right arm & 9 & $1.674(0.615)$ \\
Left leg, upper & 11 & $1.731(0.294)$ \\
Left leg, lower & 11 & $1.734(0.709)$ \\
Right leg, upper & 11 & $1.804(0.330)$ \\
Right leg, lower & 11 & $2.072(0.294)$ \\
Total manikin & 120 & $1.919(0.451)$ \\
Absorbance corrected & 120 & $1.985(0.466)$ \\
\hline
\end{tabular}

the variation between their measured heat flux output responses. The system met the $\pm 5 \%$ ASTM F1930 variation specification.

All materials were tested at fire exposure durations of $4 \pm 0.2$ and $3 \pm 0.2 \mathrm{~s}$ (Figure 2). The flame-retardant textiles were tested in a random order. Temperature and gas samples were taken continuously from the $5 \mathrm{~s}$ prior to the point 


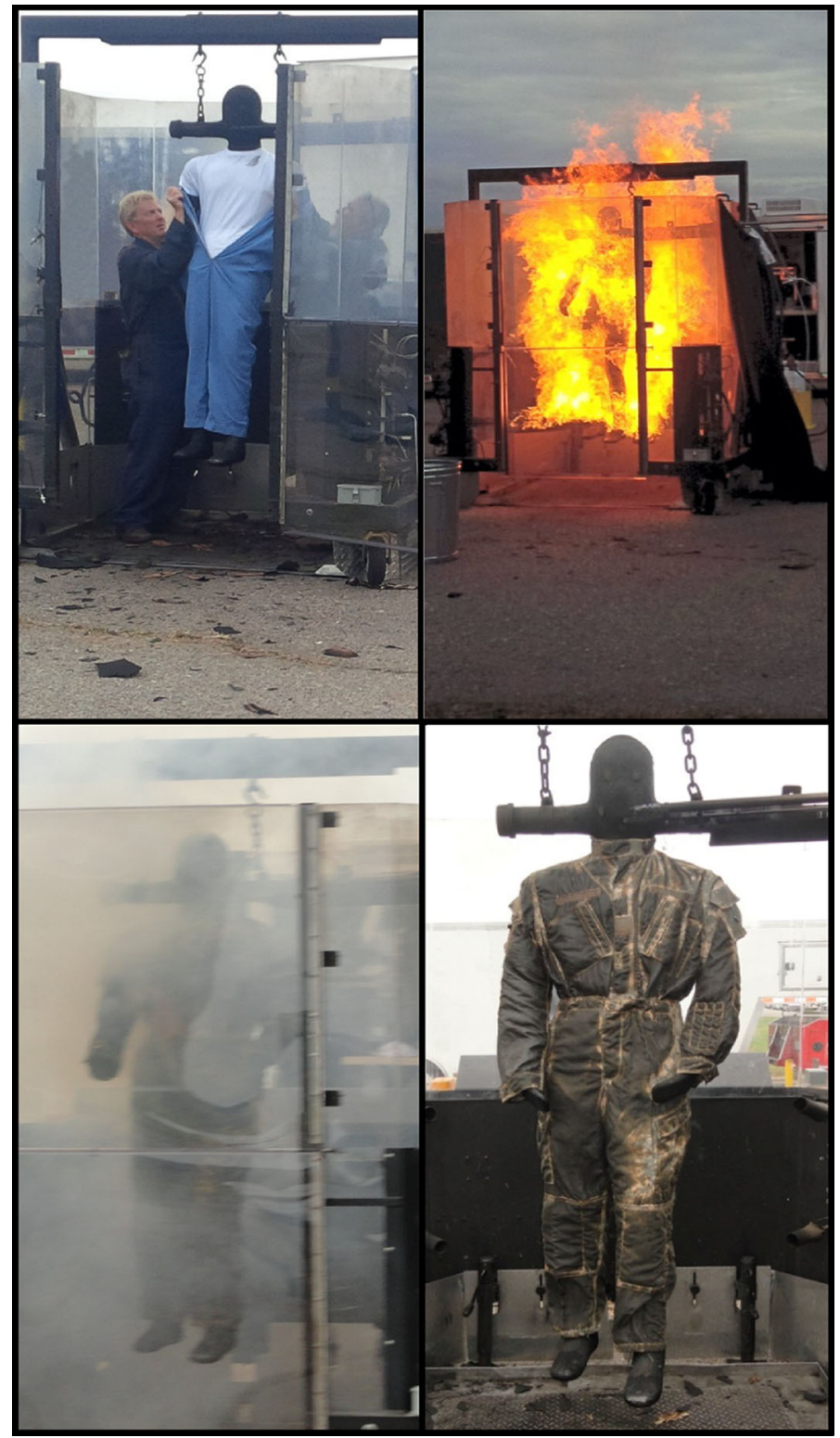

Figure 2. Material testing process using the propane-fueled flash simulator. Preparation for testing (top left), test fire exposure (top right), post-exposure (bottom left), and termination of the test (bottom right).

of ignition for a minimum of $45 \mathrm{~s}$ post-ignition. Gas samples were collected via stainless steel sampling probes positioned with a horizontal opening at the center of the manikin's breathing zone. Co-located with this was a K-type thermocouple 
for gas temperature measurements. The Fourier-transform infrared spectrophotometer (FTIR, Model Multigas 2030, MKS Instruments, Inc.) was set up to acquire data via modified EPA Method 320 [10] with a nominal $200 \mathrm{~ms}$ averaging time. The probe was connected through a heated filter and $1 / 4$ inch Teflon ${ }^{\circledR}$ sample line (maintained at $191 \mathrm{C}$ ) to a flow-through cell in the FTIR maintained at the same temperature. The test cell had a path length of $5.11 \mathrm{~m}$ and a volume of $200 \mathrm{ml}$. Flow rate was maintained at $81 / \mathrm{m}$. Tests with ethylene span gas indicated a residence time of $5 \mathrm{~s}$ in the heated sample line. Ambient air field blanks and propane-only field blanks were collected twice daily to ensure against instrument drift. Concentrations of hydrogen chloride, hydrogen cyanide, nitrogen oxides, and sulfur dioxide were reported five times per second as the mean of five $40 \mathrm{~ms}$ scans. Data were collected and logged in real time during the fire exposure and post-exposure periods of the test. Quantification was performed using the MG200 software that uses least squares regression and spectral absorbance relative to a reference to determine gas concentrations. The system also automatically compensates for common spectra (e.g., water, carbon dioxide) to minimize interference.

Along with the FTIR port, an additional probe was connected by a 5 foot long 1/8-inch ID stainless steel line to a stainless steel respirable dust cyclone and filter cassette (Model GK 2.69, BGI USA, Inc.). The steel line was directly connected to introduce the particulate into the cyclone body at the correct orientation. Small diameter lines were used to accelerate the sample air thereby limiting depositional loss. The cyclone was calibrated to obtain a $50 \%$ mass median aerodynamic diameter of $4 \mu \mathrm{m}$ at a flow rate of 4 liters of air per minute. The respirable particulate was captured on 37-mm-diameter quartz fiber filters (one per test). Filters were individually analyzed for antimony by NIOSH Method 7303 [11]. All particulate sampling probes and lines were rinsed between each fire exposure with acetone to prevent cross contamination.

\subsection{Inhalation and Toxicant Accumulation Models}

The data collected in each of the tests were used to calibrate a gas exposure model. The model was intended to determine the risk of adverse health effects resulting from exposure to combustion gases generated by the flame-retardant textiles worn by the receptor. Hence, gas temperature and combustion product concentrations are inextricably linked and must be considered together. Thermal transfer from hot gases to airway tissues was projected based on the model of Hanna and Scherer as modified by Lv et al. $[12,13]$ The equation for the heat transfer rate from the inhaled air to the tissues of the respiratory tract was based on the sum of the radiant and convective thermal transfer, the heat capacity of the tissue, and the rate at which the said thermal energy can be dissipated through the body bulk was as follows:

$$
\frac{\partial T}{\partial t}=\frac{K}{\rho C_{t}}\left(\frac{\partial^{2} T}{\partial r^{2}}+\frac{1}{r} \frac{\partial T}{\partial r}+\frac{\partial^{2} T}{\partial z^{2}}+\left(T_{a r t}-T\right) \frac{W_{b} C_{b}}{K}+\frac{Q_{m}}{K}\right) .
$$

Definitions and default values for the parameters are provided in Table 3. 


\section{Table 3}

Nomenclature and Default Values for Variable Parameters Used in the Thermal Flux and Burn Models

\begin{tabular}{|c|c|c|c|}
\hline Abrv. & Definition & Default values $^{\mathrm{a}}$ & Units \\
\hline $\mathrm{A}_{\mathrm{z}}$ & Cross-sectional area at point $\mathrm{z}$ & Table 4 & $\mathrm{~m}^{2}$ \\
\hline$a_{z}$ & Radius of airway and point $\mathrm{z}$ & Location specific & $\mathrm{m}$ \\
\hline$b_{z}$ & Radius of the circulatory domain at point $\mathrm{z}$ & Location specific & $\mathrm{m}$ \\
\hline $\mathrm{C}_{\mathrm{t}}$ & Specific heat of airway tissue & 4,000 & $\mathrm{~J} \mathrm{~kg}^{-1{ }^{\circ}} \mathrm{C}^{-1}$ \\
\hline $\mathrm{C}_{\mathrm{a}}$ & Specific heat of the air & 1,005 & $\mathrm{~J} \mathrm{~kg}^{-1 \circ} \mathrm{C}^{-1}$ \\
\hline $\mathrm{C}_{\mathrm{b}}$ & Specific heat of the blood & 4,000 & $\mathrm{~J} \mathrm{~kg}^{-1 \circ} \mathrm{C}^{-1}$ \\
\hline $\mathrm{C}_{\mathrm{He}}$ & Hanna exhalation coefficient & Table 4 & \\
\hline $\mathrm{C}_{\mathrm{Hi}}$ & Hanna inspiration coefficient & Table 4 & \\
\hline$c_{z}$ & Airway circumference at point $\mathrm{z}$ & Location specific & $\mathrm{m}$ \\
\hline$\Delta \mathrm{E} / \mathrm{R}$ & Activation energy of tissue injury & $39,109.8$ & $\mathrm{~K}$ \\
\hline $\mathrm{H}_{\mathrm{w}}$ & Water's latent heat of vaporization & $2.43 \times 10^{6}$ & $\mathrm{~J} \mathrm{~kg}^{-1}$ \\
\hline $\mathrm{h}_{\mathrm{fm}}$ & Coefficient of heat convection from mucosa to air & See text & $\mathrm{W} \mathrm{m}{ }^{-2 \circ} \mathrm{C}^{-1}$ \\
\hline $\mathrm{h}_{\mathrm{ft}}$ & Coefficient of heat convection from tissue to air & 50 & $\mathrm{~W} \mathrm{~m}{ }^{-2 \circ} \mathrm{C}^{-1}$ \\
\hline $\mathrm{L}$ & Total linear length of the airway & 0.6 & $\mathrm{~m}$ \\
\hline $\mathrm{m}$ & $\begin{array}{l}\text { Coefficient of water penetration through the } \\
\text { mucosa }\end{array}$ & $1.27 \times 10^{-6}$ & $\mathrm{~kg} \mathrm{~s}^{-1} \mathrm{~m}^{-2} \mathrm{~Pa}$ \\
\hline $\mathrm{K}$ & Thermal conductivity of tissue & 0.5 & $\mathrm{~W} \mathrm{~m}{ }^{-1 \circ} \mathrm{C}^{-1}$ \\
\hline $\mathrm{P}$ & Weaver's burn coefficient & $\begin{array}{l}t<50^{\circ} \mathrm{C}: 3.10 \times 10^{98} \\
t>50^{\circ} \mathrm{C}: 1.823 \times 10^{51}\end{array}$ & $\begin{array}{l}\mathrm{s}^{-1} \\
\mathrm{~s}^{-1}\end{array}$ \\
\hline $\mathrm{P}_{\mathrm{z}}$ & Saturated vapor pressure of tissue temperature at $\mathrm{z}$ & Temp. specific & $\mathrm{kPa}$ \\
\hline $\mathrm{P}_{\mathrm{az}}$ & Saturated vapor pressure of air temperature at $\mathrm{z}$ & Temp. specific & $\mathrm{kPa}$ \\
\hline$\varphi$ & Relative humidity of air (proportional) & Temp. specific & \\
\hline $\mathrm{Q}_{\mathrm{m}}$ & Metabolic rate of tissue in circulatory domain & 420 & $\mathrm{~W} \mathrm{~m}^{-3}$ \\
\hline r & $\begin{array}{l}\text { Radial distance within airway from the spatial } \\
\text { center }\end{array}$ & Location specific & $\mathrm{m}$ \\
\hline $\mathrm{R}_{\mathrm{e}}$ & Reynolds's number & Table 4 & \\
\hline$\rho_{\mathrm{t}}$ & Tissue density & 1,000 & $\mathrm{~kg} \mathrm{~m}^{-3}$ \\
\hline$\rho_{\mathrm{a}}$ & Air density ${ }^{\mathrm{b}}$ & 1.165 & $\mathrm{~kg} \mathrm{~m}^{-3} @ 20^{\circ} \mathrm{C}$ \\
\hline $\mathrm{Sc}$ & Schmidt number for naphthalene & $2.5^{\mathrm{c}}$ & \\
\hline $\mathrm{T}$ & Tissue temperature & Condition specific & ${ }^{\circ} \mathrm{C}$ \\
\hline $\mathrm{T}_{\mathrm{a}}$ & Air temperature & Temp. specific & ${ }^{\circ} \mathrm{C}$ \\
\hline $\mathrm{T}_{\text {art }}$ & Arterial temperature & $37-1=$ & ${ }^{\circ} \mathrm{C}$ \\
\hline t & Time in inhalation/exhalation cycle & Condition specific & s \\
\hline$t_{c}$ & Critical time at defined temperature for burns & Condition specific & s \\
\hline $\mathrm{Va}$ & Inhalation rate & $7.74 \times 10^{-4 d}$ & $\mathrm{~m}^{3} / \mathrm{s}$ \\
\hline $\mathrm{V}_{\mathrm{z}}$ & Velocity of air at $z$ & Location specific & $\mathrm{m} \mathrm{s}^{-1}$ \\
\hline $\mathrm{W}_{\mathrm{b}}$ & Blood perfusion rate in circulatory domain & 0.5 & $\mathrm{~kg} \mathrm{~m}^{-3} \mathrm{~s}^{-1}$ \\
\hline $\mathrm{z}$ & $\begin{array}{l}\text { linear distance within the airway from the nasal } \\
\text { nairs }\end{array}$ & Location specific & $\mathrm{m}$ \\
\hline$\Omega$ & Henriques' burn integral & $>0.53$ & \\
\hline
\end{tabular}

\footnotetext{
a Default parameter values were taken from reference Lv et al. [13] unless otherwise noted

b Model showed very little sensitivity to temperature-dependent density changes in air

c Value taken from Hanna and Scherer [12]

${ }^{\mathrm{d}}$ Value derived from the work of Linn et al. [15]
} 
Conserving the assumption that the heat flux is zero at the end of inhalation and prior to subsequent exhalation (i.e., thermal equilibrium), the boundary conditions can be defined as follows:

$$
\begin{aligned}
& r \equiv a_{z} \rightarrow b_{z}, \quad \frac{\partial T}{\partial r}=\frac{1}{K}\left(h_{f m}\left(T-T_{a}\right)+H_{w} m\left(P_{z}-\phi P_{a z}\right)\right) \rightarrow 0, \\
& z \equiv 0 \rightarrow L, \quad \frac{\partial T}{\partial z}=\frac{h_{f t}\left(T-T_{a}\right)}{K} \rightarrow 0 .
\end{aligned}
$$

The convection of heat between the mucosa and air $\left(\mathrm{H}_{\mathrm{fm}}\right)$ is very sensitive to the specific geometry of the airway and varies between inspiration and exhalation. Heat convection coefficients were determined based on the observation of Hanna and Scherer for naphthalene vapor absorption [14].

$$
h_{f m}=C_{H} R_{e}^{0.984} S c^{1 / 3} .
$$

The Hanna coefficient $\left(\mathrm{C}_{\mathrm{H}}\right)$ for inspiration $\left(\mathrm{C}_{\mathrm{Hi}}\right)$ and exhalation $\left(\mathrm{C}_{\mathrm{He}}\right)$ as well as the Reynolds numbers ( $\mathrm{Re}$ ) for the various subunits of the upper airway are listed in Table 4.

Concurrent with the thermal flux between the ambient air and the tissues, the thermal content of the air temperature $\left(\mathrm{T}_{\mathrm{a}}\right)$ changes by a rate defined as follows:

$$
\frac{\partial T_{a}}{\partial t}=\frac{\partial T_{a}}{\partial z} \frac{V_{z}}{A_{z}}+\frac{c_{z}}{\rho_{a} C_{a} A_{z}}\left(h_{f m}\left(T-T_{a}\right)+H_{w} m\left(P_{z}-\phi P_{a z}\right)\right) .
$$

In our exposure model, it was assumed that an individual would experience a typical breathing rate of 20 breaths per minute or one every $3 \mathrm{~s}$. The inhalation and

\section{Table 4}

Parameters and Convection Coefficients Used in Modeling Heat Flux in the Upper Airway

\begin{tabular}{lccccc}
\hline Airway segment & Medial length $^{\mathrm{a}}(\mathrm{cm})$ & Cross-sectional $\mathrm{area}^{\mathrm{b}}\left(\mathrm{cm}^{2}\right)$ & $C_{H i}^{b}$ & $C_{H e}^{b}$ & $R_{e}^{b}$ \\
\hline Nostril & 0.500 & 3.14 & 0.056 & 0.017 & 2.0 \\
Proximal nasal cavity & 3.89 & 0.867 & 0.056 & 0.017 & 4.0 \\
Tubinates & 4.17 & 1.50 & 0.129 & 0.039 & 4.0 \\
Nasopharynx & 4.17 & 1.50 & 0.048 & 0.0152 & 1.7 \\
Oropharynx & 3.61 & 2.00 & 0.046 & 0.0153 & 2.3 \\
Hypopharynx & 1.94 & 2.87 & 0.076 & 0.0254 & 2.1 \\
Larynx & 1.11 & 1.43 & 0.046 & 0.0146 & 1.1 \\
Trachea & 5.61 & 1.30 & 0.039 & 0.0126 & 2.75 \\
Bronchiopulmonary & $35.7^{\mathrm{c}}$ & $\mathrm{nd}^{\mathrm{d}}$ & $\mathrm{nd}$ & $\mathrm{nd}$ & $\mathrm{nd}$ \\
\hline
\end{tabular}

\footnotetext{
a Values taken from Hanna and Scherer 1986 [14]

b Values taken from Hanna and Scherer 1986 [12]

${ }^{c}$ Value represents total rather than medial bronchopulmonary length

d Not determined (nd) in the model. Ventilation from the bronchopulmonary assume to be at normal body temperature at exhalation
} 
exhalation phases were split evenly into the two exclusive events of $1.5 \mathrm{~s}$ per breath with an average ventilation rate of $1.44 \mathrm{~m}^{3} / \mathrm{h}$ or $7.78 \mathrm{ml} / \mathrm{s}$ during inhalation [15]. The model examined 10 defined regions of the airway from the nostrils to the bronchopulmonary tissues. While air temperature was estimated throughout the airway based on the boundary conditions defined, tissue temperature was only considered to be certain down to the distal trachea due to complexity in system branching.

Manifestation of tissue damage was superimposed on the thermokinetic model using the Henriques and Moritz omega burn integration as follows [16].

$$
\Omega=\int_{t=0}^{t_{c}} P \cdot e^{-\frac{\Delta E}{R T}} d t .
$$

The integral was applied to determine the critical time to burn $\left(t_{c}\right)$ at a given tissue temperature $(T)$ at the air/mucosal interface. If $t_{c}$ was exceeded at $T$, then the tissue was deemed to incur second degree burns. If $t_{c}$ is exceeded by a factor greater than 2, then conductance to the basal layer will result in irreversible damage [17]. The air/mucosal/epithelial boundaries were unified into a single interface to simplify the integration. Given the high temperature gradient in this application, this is likely to have had inconsequential impacts on the results.

\subsection{Gas Inhalation Risk Assessment}

The apparel tested was not intended for use by firefighters. Rather, it is occupational apparel intended to protect an individual in the event of an acute occupational emergency situation such as an explosion, a flashover, and an arc flash. We used the intention of the apparel to develop the maximum likely exposure scenario to assess the risks associated with the garments' combustion.

Maximum reasonable exposure to the gases generated by the garment will occur to the principal (individual assumed to be caught in the flash fire) if he remains immobile in a standing position. Movement by the principal will displace the breathing zone from the location of gas generation. Change in posture from standing to sitting, kneeling, or prone will either increase cross-sectional area of the gas cloud (reducing concentrations) or move the breathing zone out of the area of maximum concentration.

Maximum exposure time for the principal was assumed to be $20 \mathrm{~s}$ post-ignition or at the inhibition of voluntary ventilation (apnea) expected when third degree burns of the larynx are received. The $20 \mathrm{~s}$ maximum was based on the assumption that in the occurrence of a flash fire event, it would not be reasonable to expect the principal to stand still for any longer after combustion was concluded. They would be expected to either collapse or move laterally. If the principal were to do either, then the exposure concentrations would be significantly reduced since the breathing zone would have moved out of the gas column formed as hot combustion gases move upward from the garment into the principal's breathing zone. Results indicated that gas concentrations were reduced by 10 -fold just $30 \mathrm{~s}$ postignition and returned to background concentrations within $60 \mathrm{~s}$ in the open 
chamber scenario. In a standard room such as a motor control center, buoyant gases would also rise and disperse resulting in lower concentrations within the breathing zone.

Third person exposure was assumed to represent someone not involved in the event, but coming to the aid of the principal having experienced a flash fire. Risk to such individuals was evaluated based on combustion gas inhalation after the principal's fire exposure was concluded. Because of the buoyancy of the high temperature gas, the only way a third person would be exposed is if their breathing zone was directly above the burned individual. Lateral movement of the gases would only occur as the result of external convections and thermal expansions which, given the buoyancy of the superheated air, would be expected to be minimal. The third person exposure is assumed to occur over a prone individual resulting in a 7-fold increase in the cross-sectional area of the gas plume. The third person was assumed to enter the combustion gas plume $3 \mathrm{~s}$ after the end of the flash event for a duration of $90 \mathrm{~s}$. At the end of this period, the air temperature and gas concentrations have, for the most part, returned to background ambient conditions.

For a non firefighter, being involved in a flash fire with no respiratory protection is a very low frequency, low duration, high impact event. Because exposure to elevated gas concentrations occurs on the order of a few seconds, the toxic impact of the gases for the principal individual involved in the flash was determined on a health based rather than an occupational compliance standard. Exposure was determined using the same respiratory factors used in the evaluation of heat injury (20 breaths per minute split evenly between inhalation and exhalation; $778 \mathrm{ml} / \mathrm{s}$ at inhalation). For all respiratory toxicants, exposure was determined as the sum of the inhaled amount of the gas or particulate over the period of exposure. Because of the brief and severe nature of the exposure, risk was evaluated based on acute non-lethal impacts that would either complicate other injuries or limit the principal's ability to escape dangerous situations. This included any physical impedance (paralysis, loss of consciousness, blindness, etc.) that may reduce the survivability of a person involved in a flash fire. Toxicity values used in the risk assessment are presented in Table 5. Derivations of comparative threshold values are discussed in the following.

2.3.1. Hydrogen Chloride. Hydrogen chloride is a pungent colorless gas formed in the combustion of materials that contain chlorine. It is a hygroscopic acid gas that forms hydrochloric acid upon contact with water. Its toxicity is based on the acidification of exposed membranes resulting in localized inflammation and necrosis. Derivation of a $20 \mathrm{~s}$ acute hazard limit was based on a study in Tabulae Biologicae Periodicae as referenced by the CDC on the development of the IDLH (immediately dangerous to life or death) level of $50 \mathrm{ppm}[18,19]$. The IDLH was derived on an observation of lowest impact during a 5-min exposure to hydrogen chloride of $3,000 \mathrm{ppm}\left(4,830 \mathrm{mg} / \mathrm{m}^{3}\right)$. A 5-min exposure at 3,000 ppm equates to a total body burden of $580 \mathrm{mg}$ for a typical male. The IDLH for hydrogen chloride is $80.4 \mathrm{mg} / \mathrm{m}^{3}$ or $57.8 \mathrm{mg}$ over a $90 \mathrm{~s}$ exposure period. 


\section{Table 5 \\ Hazard Thresholds Used to Evaluate the Risk of Impact to the Principal and Third Parties From Combustion Gases Generated by the Fire Re- tardant Textiles}

\begin{tabular}{llllll}
\hline \multirow{2}{*}{ Chemicals } & \multicolumn{2}{c}{ Principal's Exposure } & & \multicolumn{2}{c}{ 3rd Person's exposure } \\
\cline { 2 - 3 } & \multicolumn{1}{c}{ Endpoint } & $\begin{array}{c}20 \mathrm{~s} \text { exposure } \\
(\mathrm{mg})\end{array}$ & & $\begin{array}{c}\text { IDLH } \\
\left(\mathrm{mg} / \mathrm{m}^{3}\right)\end{array}$ & $\begin{array}{c}90 \mathrm{~s} \text { exposure } \\
(\mathrm{mg})\end{array}$ \\
\hline Hydrogen chloride & Respiratory burns & 580 & & 80.4 & 57.8 \\
Hydrogen cyanide & Neurological effects & 20.1 & & $\mathrm{~N} / \mathrm{A}^{\mathrm{a}}$ & 22.8 \\
Nitrogen dioxide & Respiratory burns & 9.22 & & 40.5 & 29.2 \\
Sulfur dioxide & Respiratory burns & 54.2 & & 282 & 203 \\
Antimony (particulate) & Respiratory burns & 8,390 & & 50 & 193 \\
\hline
\end{tabular}

All chemicals were evaluated based on cumulative inhalation exposure for the assumed periods of threat. Evaluation for the principal was based on thresholds likely to aggravate thermal injuries or impede escape. Third person thresholds were based on the 30-min IDLH time weighted to $90 \mathrm{~s}$ of exposure

${ }^{a}$ Because cyanide toxicity decreases with the duration of exposure, 3 rd person thresholds were derived from a regression of no-effect concentrations against duration of exposure. Threshold values are less than would be predicted based on the IDLH $(160 \mathrm{mg})$

2.3.2. Hydrogen Cyanide. Hydrogen cyanide is a combustion gas produced when carbon and nitrogen are burned together. Hydrogen cyanide is a respiratory inhibitor that blocks intracellular energy metabolism. Systemic injury occurs when blood and brain concentrations are sufficient to shut down cellular activity and oxygen transport resulting in progressive neurological impairment leading to unconsciousness [20]. Because cyanide is metabolized very quickly in vivo, the no-effect threshold decreases with the duration of exposure. This is in opposition to the other contact toxicants considered here where, within the short periods of exposure involved, the thresholds of safe exposure increase as the duration of exposure decreases in agreement with the Haber Rule. To determine the impact threshold for a $20 \mathrm{~s}$ exposure to hydrogen cyanide, no-effect concentrations measured in humans were regressed against duration of exposure (Figure 3). From this $95^{\text {th }}$ percent lower confidence limit of the prediction, the threshold exposure was taken at a $20 \mathrm{~s}$ exposure duration. The resulting allowable exposure threshold for cyanide was determined to be $20.1 \mathrm{mg}$ over $20 \mathrm{~s}$. This should be considered safe and conservative given that the lethal exposure rate for this time interval is less than the $120 \mathrm{mg}$ exposure assumed in EPA's acute exposure guideline level (AEGL; based on a 10-min exposure window) and the $77.0 \mathrm{mg}$ threshold based on sub-lethal acute inhalation studies in rats $[21,22]$. For the third party exposure threshold, the $95^{\text {th }}$ percent lower confidence limit was again used to derive a total exposure of $20.8 \mathrm{mg}$ for a $90 \mathrm{~s}$ exposure.

2.3.3. Nitrogen Oxides. Of the typical nitrogen oxide species, nitrogen dioxide is the most toxic and therefore was used as a conservative surrogate in this analysis. Nitrogen dioxide is a severe respiratory irritant. Like hydrogen chloride, nitrogen dioxide is highly hygroscopic and produces nitric acid when mixed with water in the mucosal lining of the airway. Short-term exposures to high concentrations of 


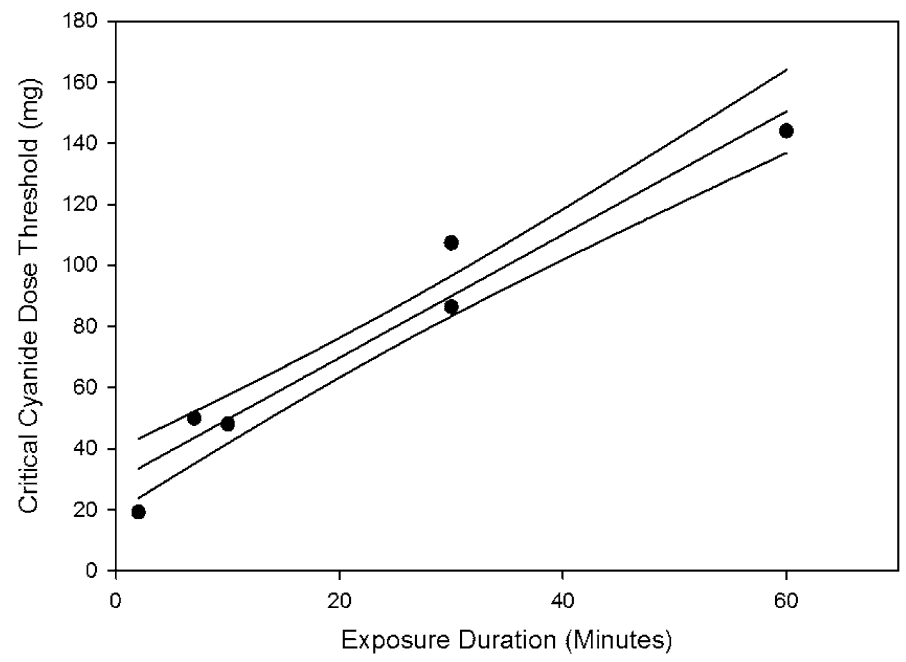

\section{Figure 3. Linear regression of cyanide toxicity ( $\mathrm{mg}$ ) with time ( $t$ ) in minutes. The equation of the relation is $29.5+2.02+\left(r^{2}=0.947\right)$. The equation of the $95 \%$ confidence interval is $19.3+2.31 t-0.006 t^{2}$.}

nitrogen dioxide have been an issue for the military since it is a common product of propellant combustion [23]. The current US army standard for live fire testing is $125 \mathrm{ppm}\left(256 \mathrm{mg} / \mathrm{m}^{3}\right)$ for $30 \mathrm{~s}$ with a negligible risk for injury or incapacitation at three times the resting ventilation rate [24]. Assuming a resting ventilation rate, the concentration exposure rate of $20 \mathrm{~s}$ is assumed to be $9.22 \mathrm{mg}$. The IDLH for nitrogen dioxide is $40.5 \mathrm{mg} / \mathrm{m}^{3}$ or $29.2 \mathrm{mg}$ over a $90 \mathrm{~s}$ period.

2.3.4. Sulfur Dioxide. Sulfur dioxide, like nitrogen dioxide and hydrogen chloride, is a respiratory irritant that produces sulfuric acid $\left(\mathrm{H}_{2} \mathrm{SO}_{4}\right)$ via the oxidation of sulfurous acid $\left(\mathrm{H}_{2} \mathrm{SO}_{3}\right)$ when mixed with water in the lining of the airway. Concentrations from 400 to $500 \mathrm{ppm}$ are considered dangerous to humans for even short periods but are not necessarily hazardous if escape is made within a few minutes [25]. Assuming an upper limit for the principal's exposure of $400 \mathrm{ppm}$ $\left(1,130 \mathrm{mg} / \mathrm{m}^{3}\right)$ for $2 \mathrm{~min}$, the exposure rate over $20 \mathrm{~s}$ would be $54.2 \mathrm{mg}$. The IDLH for sulfur dioxide is $282 \mathrm{mg} / \mathrm{m}^{3}$ or $203 \mathrm{mg}$ over a $90 \mathrm{~s}$ exposure period.

2.3.5. Antimony Trioxide (Particulate). While long-term exposure to antimony trioxide has been associated with chronic respiratory disease, its acute toxicity is very limited. Animal studies have shown that a $4 \mathrm{~h}$ exposure to $5,200 \mathrm{mg} / \mathrm{m}^{3}$ antimony $(1,119 \mathrm{mg} / \mathrm{kg})$ as antimony trioxide resulted in no outward signs and only limited symptoms of pulmonary inflammation upon necropsy (24-h or 14-day post-exposure) [26]. A 10-fold uncertainty factor was assumed upon this unbounded NOAEL (no observed adverse effect level) to account for animal to human extrapolation to yield a safe exposure of $8,395 \mathrm{mg}$ over $20 \mathrm{~s}$. NIOSH does not have 
an IDLH for antimony trioxide. Hence, the more conservative metallic antimony IDLH was applied. For this material, the IDLH is $50 \mathrm{mg} / \mathrm{m}^{3}$ with a $90 \mathrm{~s}$ exposure equivalent to $193 \mathrm{mg}$.

2.3.6. Total Acid Gases. Total acid gas impact was determined based on the toxicity thresholds identified for hydrogen chloride. This was chosen as the most representative threshold for acid deposition because it consists of the most biologically benign anion. Exposure was determined as the sum of the normality of all acid gases identified above.

2.3.7. Risk Characterization. The quantitative risk assessment for the inhalation toxicants was expressed as the hazard ratio and was defined as the quotient of the amount of exposure incurred over the above defined threshold values. The lower the magnitude of the hazard ratio, the lower the risk and the greater the margin for additional exposure prior to expecting an adverse effect that would increase injury or impede escape.

\section{Results and Discussions}

\subsection{Thermal Injury}

There has been little research on the ventilation response resulting from high intensity/ short duration exposure to extreme temperature events such as a flash fire. Being caught in a flash fire event typically results in surface burns as well as burns to the upper airway that can result in a presentation of involuntary apnea requiring immediate intubation [27]. However, no one has dissected the event to determine what level of injury results in the manifestation or cause of involuntary apnea. Research into the cough reflex and dive response suggests that the cessation of voluntary ventilation is mediated through the superior laryngeal nerve which is a major branch of the vagal nerve [28]. Extreme irritation and tissue damage about the glottis and larynx would result in an apneic reflex intended to protect the lower airway from injury [29]. While extreme irritation and cellular damage to the upper airway (nasal, buccal, and pharyngeal) are also likely to impact ventilation, both voluntary and involuntary, to our knowledge no study has ever quantified it in a manner that could be applied to consistently describe the variability in ventilation during a flash fire. If the principal voluntarily held his breath, then not only would there be no exposure to the thermal flux from the hot gases, but also there would be no inhalation exposure to any toxicants present in the combustion products. If the principal is breathing heavily, then the rate of heat flux (and burn rate) and gas exposure would increase proportionally. Since at issue is a worn garment that will only burn in the presence of a high external heat flux, gas temperature and composition are inseparable. Hence, the principal exposure model conservatively assumed that the gas exposure occurs through regular ventilation with exposure to the gases generated by the garments for $20 \mathrm{~s}$, or until third degree laryngeal burns are predicted, whichever comes first.

When high temperature air is inhaled, the heat of the air is transferred to the tissues immediately surrounding the airway thereby heating them. The thermal 
capacity of air is much lower than that of biological tissues. Exposed tissues also have a heat sink and through thermal conduction and blood flow, areas in contact with high temperatures can have the heat dissipated through the rest of the body. Hence, there is a delay in the time it takes for high temperature air to heat tissue to temperatures where there is a hazard of thermal burning. Also because the human airway is linear, there is a gradient of temperature with the most upper parts of the airway absorbing the most heat and therefore burning faster. Lower parts of the airway take longer to burn because of greater heat sink capacity and the air heat loss in the upper regions prior to reaching the lower. The change in the rate of thermal input with distance down the airway is based on the temperature of the air above body temperature, the duration of exposure, and in this case the number of standardized breaths.

With a flame exposure time of $4 \mathrm{~s}$ at a radiance of $84 \mathrm{~kW} / \mathrm{m}^{2}$, gas temperature at the breathing zone increased at a rate that can be approximated at about $145^{\circ} \mathrm{C} / \mathrm{s}$ with maximum temperatures around $650^{\circ} \mathrm{C}$. The thermal transfer model indicated that third degree burns to the nasal nares occurred almost immediately with the temperature in the nostrils rising to an excess of $160^{\circ} \mathrm{C}$ within the first half-second of inhalation (Figure 4). By the apex of the second inhalation cycle, third degree burns are expected to progress to the proximal pharyngeal airway. During exhalation, tissues distal to the nasal tubercle cool significantly. This was the result of first, transfer of heat from the tissues to the exhaled air that, as part of the boundary condition, would have achieved a temperature of $37^{\circ} \mathrm{C}$ at the end of the inhalation phase, and second, heat dissipation from the airway tissues through heat transfer to the blood and surrounding deeper tissues. However, by the middle of the fifth breath, the system is overwhelmed and the third degree burns would have progressed through the upper larynx and continued to the proximal trachea. At this point in time, involuntary apnea would be expected to occur. All long fire exposure tests showed third degree burns to the larynx during the fifth breathing cycle.

Even though the radiant heat input to the test chamber stopped at about $4 \mathrm{~s}$, gas temperature in the breathing zone was measured in excess of $350^{\circ} \mathrm{C}$ at $8 \mathrm{~s}$ after the heat input had stopped. Linear interpolation of gas cooling between the termination of radiant input and the apex of the fifth inhalation estimates the rate of gas cooling of only $30^{\circ} \mathrm{C} / \mathrm{s}$. This slower cooling appears as the result of residual heat in the test system. Because the test manikin was standing, it took 3-4 s for hot gases generated from the lower extremities to rise into the breathing zone. If the test manikin had been sitting, it would have been expected that faster temperature increases, higher temperatures, and faster cooling would have been manifest in the breathing zone. If the manikin had been prone, we would have expected lower temperatures because the hot gases would have been rising away from the breathing zone rather than rising through it.

In contrast to the long $4 \mathrm{~s}$ fire exposure times, significantly less thermal injury was predicted in the $3 \mathrm{~s}$ fire exposures (Figure 5). Maximum temperatures in the breathing zone peaked at between 460 to $485^{\circ} \mathrm{C}$ and had cooled to around $275^{\circ} \mathrm{C}$ within $8 \mathrm{~s}$ after combustion had stopped. As a result, in most tests, third degree burns within the airway were not predicted to progress past the proximal 


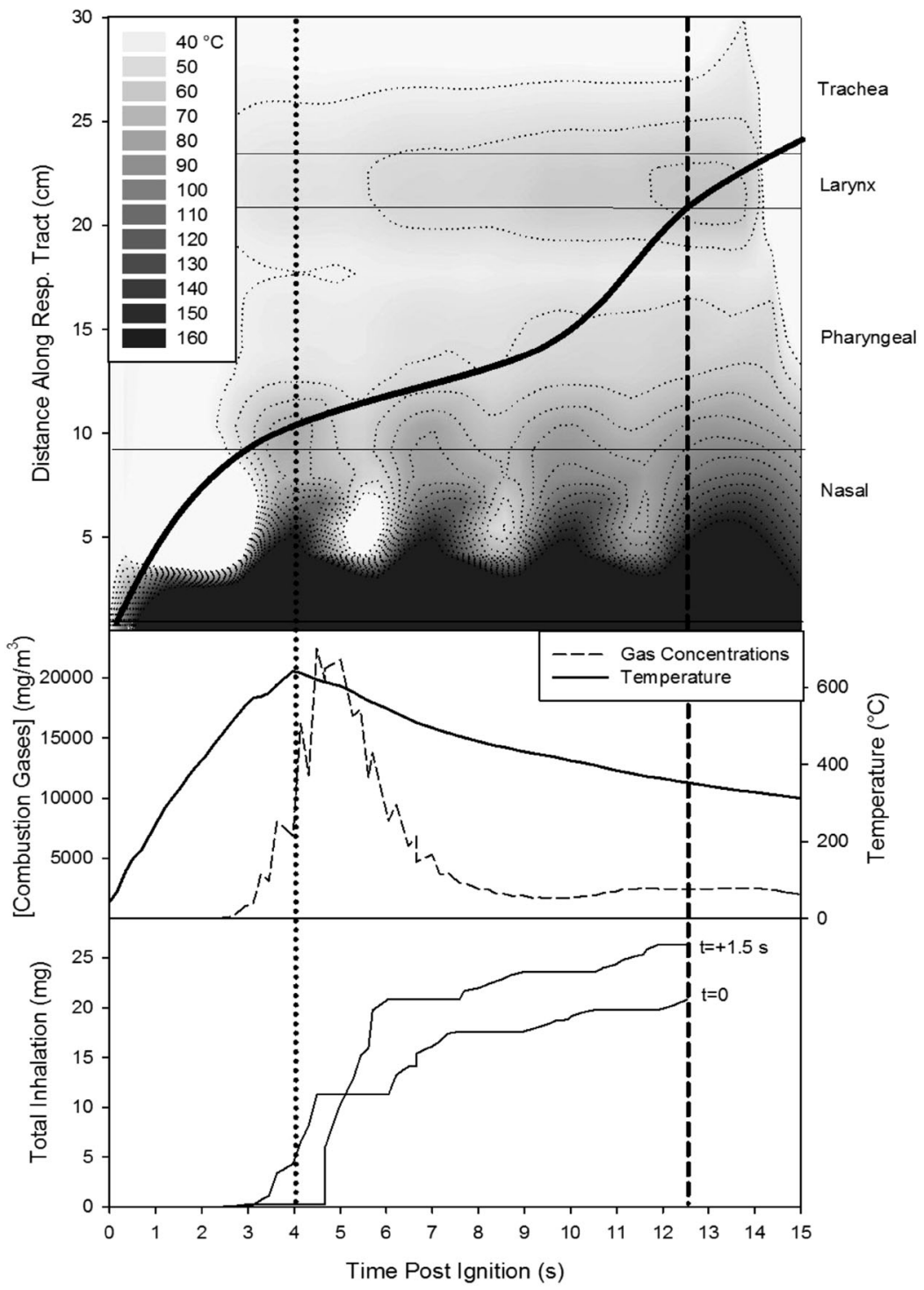

Figure 4. Results of the $4 \mathrm{~s}$ flash fire test of sample material D. Top Tissue temperature $\left({ }^{\circ} \mathrm{C}\right)$ profile (contour) and third degree burn curve (black). Middle gas temperature (solid) and total combustion gas concentration profile at the breathing zone (dash). Bottom cumulative exposure to total combustion gases for the principal from the point of ignition to the cessation of voluntary ventilation at the third degree burning of the larynx. The range represents a staggered ventilation cycle of $3 \mathrm{~s}$ per breath. Vertical dotfed line represents termination of thermal input. Vertical dashed line represents the point of assumed involuntary apnea (12.5 s post-ignition). 


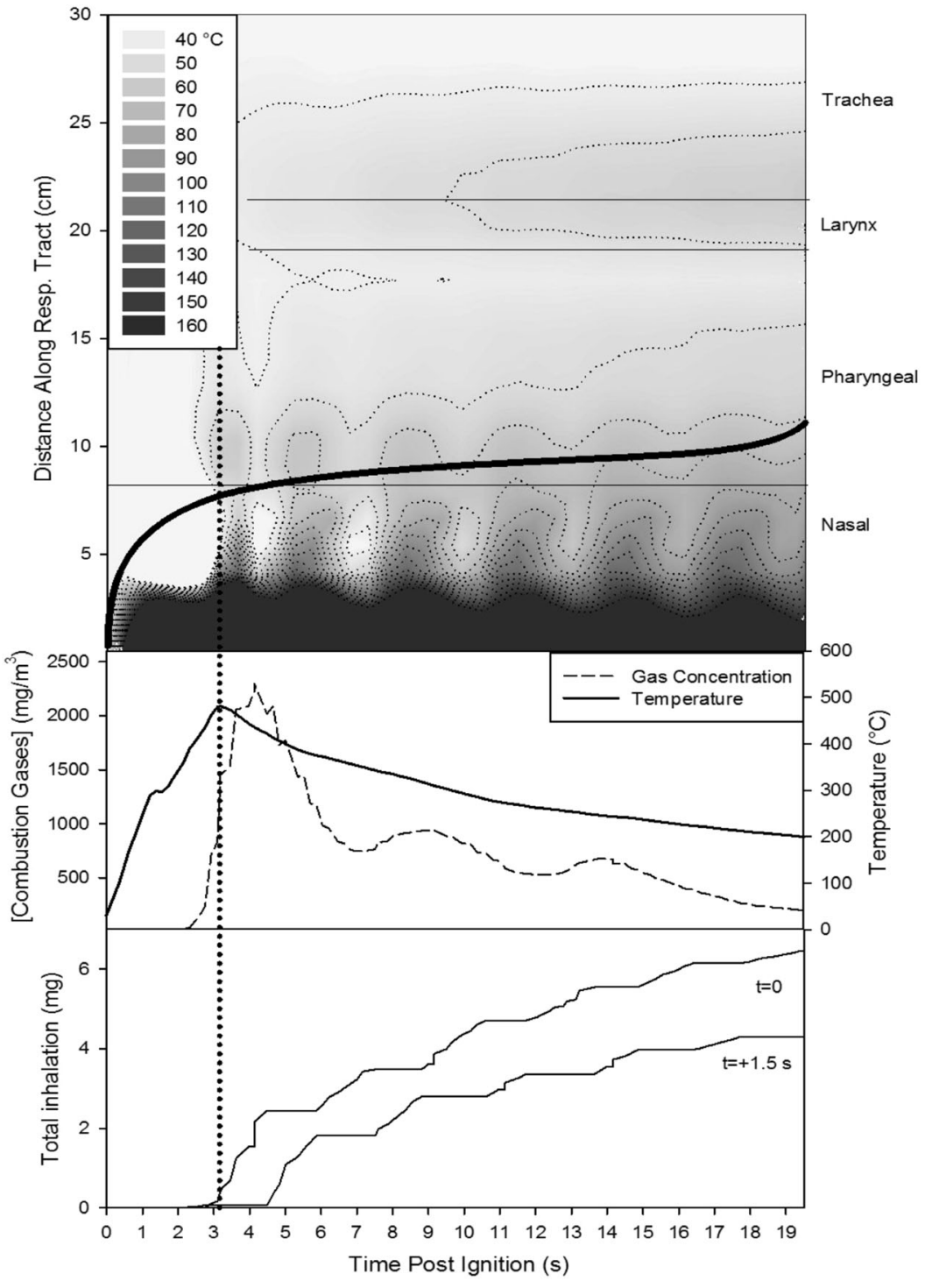

Figure 5. Results of the $3 \mathrm{~s}$ flash fire test of sample material D. Top Tissue temperature $\left({ }^{\circ} \mathrm{C}\right)$ profile (contour) and third degree burn curve (black). Middle gas temperature (solid) and gas concentration profile at the breathing zone (dash). Botfom cumulative total gas exposure for the principal from the ignition for 20 s post-ignition. The range represents a staggered ventilation cycle of 3 s per breath. Vertical doffed line represents termination of thermal input. Temperature exposure was not sufficient to produce third degree burns to the larynx. 


\section{Table 6}

Cumulative Chemical Exposure for the Principal Involved in a Flash Fire

\begin{tabular}{|c|c|c|c|c|c|c|}
\hline \multirow{2}{*}{ ID } & \multirow{2}{*}{$\begin{array}{l}\text { Max. Respir. } \\
\text { Time (s) }\end{array}$} & \multicolumn{5}{|c|}{ Exposure } \\
\hline & & $\mathrm{HCl}$ & $\mathrm{HCN}$ & $\begin{array}{l}\mathrm{NO}_{\mathrm{x}} \\
\text { mg inhaled }\end{array}$ & $\mathrm{SO}_{2}$ & $\mathrm{Sb}$ \\
\hline \multicolumn{7}{|c|}{ Long fire exposures } \\
\hline No textiles & 12.5 & 0.254 & $3.90 \times 10^{-4}$ & 0.0778 & 0.0118 & $1.86 \times 10^{-5}$ \\
\hline A & 14.0 & 15.2 & 2.090 & 0.396 & 0.0754 & 0.09780 \\
\hline B & 12.4 & 27.2 & 4.22 & 0.382 & 0.981 & 0.158 \\
\hline $\mathrm{C}$ & 12.5 & 10.69 & 2.33 & 0.667 & 0.1020 & 0.2220 \\
\hline $\mathrm{D}$ & 11.0 & 19.9 & 3.13 & 0.401 & 0.0780 & 0.0980 \\
\hline $\mathrm{E}$ & 12.4 & 14.20 & 1.95 & 0.374 & 0.0852 & 0.117 \\
\hline $\mathrm{F}$ & 11.0 & 17.7 & 3.12 & 1.16 & 0.191 & 0.127 \\
\hline G & 12.0 & $0.269^{\mathrm{a}}$ & 1.17 & 0.484 & 0.754 & $2.36 \times 10^{-5 a}$ \\
\hline $\mathrm{H}$ & 15.5 & $0.348^{\mathrm{a}}$ & 0.255 & 1.78 & $0.0107^{\mathrm{a}}$ & $1.39 \times 10^{-5 \mathrm{a}}$ \\
\hline I & 12.4 & 1.56 & 0.0463 & 1.26 & 0.779 & $2.76 \times 10^{-5 a}$ \\
\hline \multicolumn{7}{|c|}{ Short fire exposures } \\
\hline No textiles & 20.0 & 0.055 & 0.000142 & 0.0469 & 0.0118 & $1.86 \times 10^{-5}$ \\
\hline A & 20.0 & 5.07 & 0.285 & 0.0877 & 0.107 & 0.0399 \\
\hline B & 15.6 & 4.56 & 0.459 & 0.148 & 0.235 & 0.0923 \\
\hline $\mathrm{C}$ & 20.0 & 4.67 & 0.424 & 0.273 & 0.0452 & 0.266 \\
\hline $\mathrm{D}$ & 20.0 & 4.60 & 0.611 & 0.13 & 0.0428 & 0.137 \\
\hline $\mathrm{E}$ & 20.0 & 4.45 & 0.295 & 0.113 & 0.0602 & 0.116 \\
\hline $\mathrm{F}$ & 20.0 & 3.62 & 1.03 & 0.233 & 0.0552 & 0.106 \\
\hline G & 20.0 & 0.087 & 0.0503 & 0.106 & 0.272 & $3.08 \times 10^{-5 a}$ \\
\hline $\mathrm{H}$ & 18.5 & 0.325 & 0.0155 & 0.902 & $0.00688^{\mathrm{a}}$ & $4.99 \times 10^{-5 a}$ \\
\hline I & 20.0 & 0.203 & 0.0199 & 0.467 & 0.247 & $6.08 \times 10^{-5 a}$ \\
\hline
\end{tabular}

Maximum respiration time represents the exposure time from ignition to the manifestation of third degree burns in the larynx or $20 \mathrm{~s}$, whichever is less. Concentrations represent cumulative exposure from ignition to the maximum respiration time assuming standing posture

a Value not significantly greater than controls at $P=0.95$

pharyngeal region (about level with the upper buccal pharyngeal) at the $20 \mathrm{~s}$ termination of the risk assessment period. Because of this limited injury, involuntary apnea as the result of thermal exposure was not expected. The exceptions were Sample B and Sample H where third degree laryngeal burns were predicted at 15.6 and 18.5 s post-ignition, respectively (Table 6).

\subsection{Combustion Product Exposure}

The chemicals monitored were hydrogen chloride, hydrogen cyanide, nitrogen oxides (as nitrogen dioxide), sulfur dioxide, and respirable antimony particulate. Carbon monoxide and carbon dioxide could not be tracked because the propane burners were overwhelming sources of these combustion products. All of the commercial textiles tested emitted all of the gases monitored to some extent, while particulate antimony was limited exclusively to the Protex-containing textiles 
$(A-F)$. Protex's flame resistance is based on the doping of modacrylic polymer with antimony trioxide. The modacrylic blends were highest in the hydrogen chloride and hydrogen cyanide. The flame-resistant cotton $(\mathrm{H})$ was highest in nitrogen dioxide, while the cotton/nylon blend $(\mathrm{G})$ also showed generation of hydrogen cyanide and sulfur dioxide emissions. The rayon blend (I) was highest in sulfur dioxide. Cumulative exposures to combustion products for the principal receptor are listed in Table 6.

Elevated concentrations of gases related to the combustion of the flame-retardant textiles were not detected in the breathing zone until 2.5 to $3 \mathrm{~s}$ post-ignition. Likewise, maximum combustion gas concentrations were not observed at the peak of cumulative thermal energy input, but rather 0.5 to $1.5 \mathrm{~s}$ after the burners were shut down. This delay likely represents a combination of the thermal capacity of the textiles retarding their temperature increase relative to the air temperature, and the vertical transport time for the gases to move from their point of generation around the arms, trunk, and legs, and into the breathing zone of the principal.

The duration of the extreme elevated concentrations in the gases was found to be very short. In the $3 \mathrm{~s}$ fire exposures, the primary peak started at about $2.5 \mathrm{~s}$ and tapered at an inflection point around $6.8 \mathrm{~s}$. After that, combustion gas concentrations decreased with time at a rate approximately half that seen prior to the inflection. Gas temperatures during this period ranged from 350 to $500^{\circ} \mathrm{C}$. For the $4 \mathrm{~s}$ fire exposures, concentrations of combustion gases were found to be about 10 times that of the $3 \mathrm{~s}$ fire exposures with temperatures between 550 and $650^{\circ} \mathrm{C}$. However, the duration of the peaks was not significantly different with the slope inflections occurring between 2.5 and $7 \mathrm{~s}$. The post $7 \mathrm{~s}$ lag phases in both tests were also comparable with the combustion gas concentrations in the $4 \mathrm{~s}$ fire exposures being about double that observed in the $3 \mathrm{~s}$ ones.

A third party assistant to someone having endured a flash fire exposure would be expected to have a much longer exposure to the heat and combustion gases emitted from the textiles even though they could not be expected to contact the principal until after exposure to the engulfing fire is completed. A contact $3 \mathrm{~s}$ after fire exposure was felt to be conservative since such a rapid response would require the third person to be both ready and immediately present. Contact at $3 \mathrm{~s}$ postcombustion captures the end of the peak and the entire lag phase of gas production from the textiles. Significant elevation of combustion gas concentrations (compared to controls) from the $4 \mathrm{~s}$ fire exposures lasted approximately $40 \mathrm{~s}$ postignition (Figure 6). Whereas, the duration of significant elevation in the $3 \mathrm{~s}$ fire exposures was around $25 \mathrm{~s}$ (Figure 7). From that point, gas generation from the textiles could not be discerned from the background concentrations for the respective gases. Cumulative values of exposure for the third party are listed in Table 7.

\subsection{Risk Associated with Combustion Product Exposure}

Within the context of the incurred thermal injuries, the health risks associated with inhalation of the combustion gases was evaluated in terms of the hazard ratio. None of the respiratory exposures to the principal were found to exceed the 


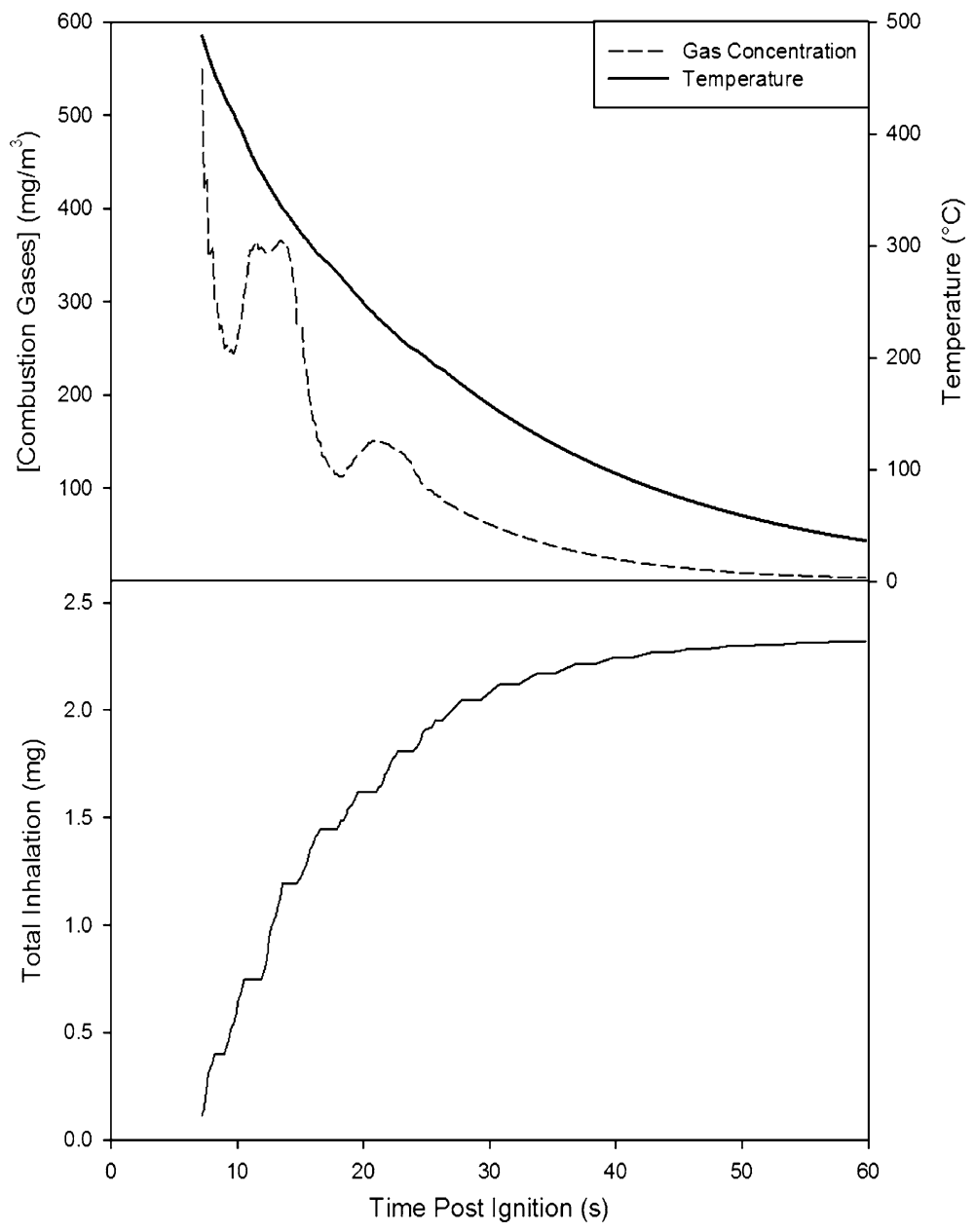

Figure 6. Exposure for third person aid providers while assisting a prone individual after exposure to flash fire conditions for $4 \mathrm{~s}$ (Material D). The assisting individual's breathing zone is assumed to enter the zone $40 \mathrm{~cm}$ above the smoldering apparel $3 \mathrm{~s}$ after the termination of the fire exposure. Top Air temperature (solid) and gas concentration (dash) profile at the third person's breathing zone. Botfom cumulative gas exposure for the third person aid from $3 \mathrm{~s}$ post-fire exposure (7.2 s post-ignition) for 60 s. Temperature exposure was not sufficient to produce third degree burns to the larynx.

threshold doses for the respective gases (Figure 8). As a result, it would not be expected that contributing injury or irreversible adverse effects would occur as the result of exposure to the combustion gases released from the flame-retardant garments. Therefore, it can be concluded that under flash fire conditions, exposure of the principal through the inhalation of these hazardous combustion gases will not 


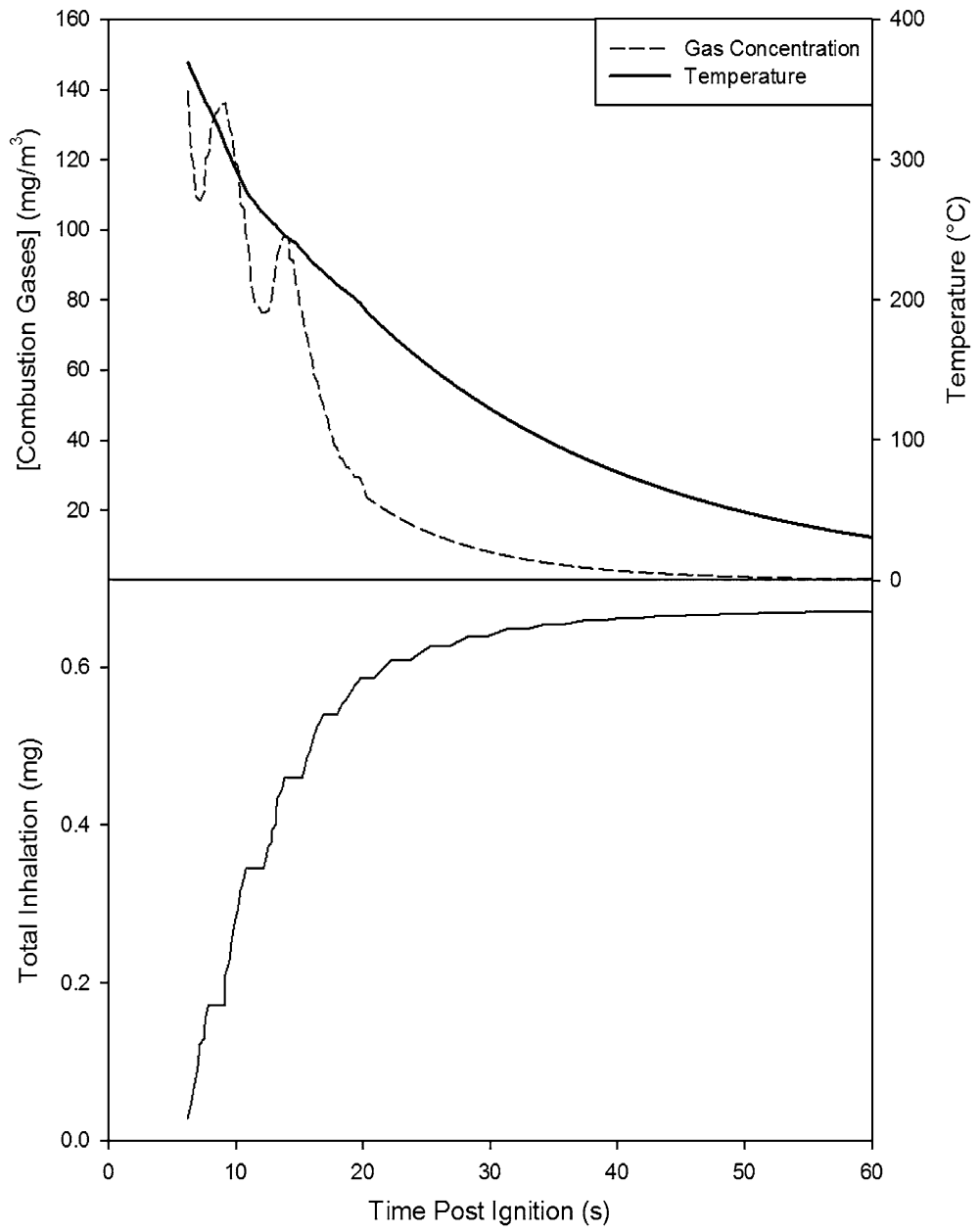

Figure 7. Third person exposure likely to occur while assisting a prone individual exposed to flash fire conditions for $3 \mathrm{~s}$ (Material D). The assisting individual's breathing zone is assumed to enter the zone $40 \mathrm{~cm}$ above the smoldering apparel $3 \mathrm{~s}$ after the termination of the fire exposure. Top Air temperafure (solid) and gas concentration profile (dash) at the third person's breathing zone. Botfom cumulative gas exposure for the third person assistant from 3 s post-fire exposure (6 s post-ignition) for 60 s. Temperature exposure was not sufficient to produce third degree burns to the larynx.

add to the health impacts associated with respiratory burns from exposure to the heat generated by the actual fire.

As seen with the principal, there was no detected hazard to the third party aid as the result of exposure to textiles immediately after the fire exposure event when 


\section{Table 7}

Cumulative Chemical Exposure to Third Persons Assisting Burned Individual

\begin{tabular}{|c|c|c|c|c|c|}
\hline \multirow{2}{*}{ ID } & \multicolumn{5}{|c|}{ Exposure } \\
\hline & $\mathrm{HCl}$ & $\mathrm{HCN}$ & $\begin{array}{l}\mathrm{NO}_{\mathrm{x}} \\
\mathrm{mg} \text { inhaled }\end{array}$ & $\mathrm{SO}_{2}$ & $\mathrm{Sb}$ \\
\hline \multicolumn{6}{|c|}{ Long fire exposures } \\
\hline Control & 0.0244 & $1.04 \times 10^{-4}$ & $5.72 \times 10^{-4}$ & 0.0115 & $1.86 \times 10^{-5}$ \\
\hline A & 0.895 & 0.135 & 0.0111 & $0.00913^{\mathrm{a}}$ & 0.00635 \\
\hline B & 1.39 & 0.252 & 0.0125 & 0.0522 & 0.00946 \\
\hline $\mathrm{C}$ & 1.046 & 0.285 & 0.025 & $0.018^{\mathrm{a}}$ & 0.027 \\
\hline $\mathrm{D}$ & 0.206 & 0.505 & 0.0161 & $0.0262^{\mathrm{a}}$ & 0.0159 \\
\hline $\mathrm{E}$ & 2.28 & 0.44 & 0.0195 & $0.0153^{\mathrm{a}}$ & 0.0264 \\
\hline $\mathrm{F}$ & 2.81 & 1.45 & 0.327 & 0.102 & 0.058 \\
\hline $\mathrm{G}$ & 0.555 & 1.007 & 0.366 & 0.743 & $2.02 \times 10^{-4}$ \\
\hline $\mathrm{H}$ & 0.098 & 0.0244 & 0.01060 & 0.487 & $9.59 \times 10^{-5}$ \\
\hline I & 0.253 & $0.00863^{\mathrm{a}}$ & 0.00969 & 0.0964 & $5.15 \times 10^{-5}$ \\
\hline \multicolumn{6}{|c|}{ Short fire exposures } \\
\hline Control & 0.0111 & $1.16 \times 10^{-4}$ & $6.02 \times 10^{-4}$ & 0.00170 & $1.86 \times 10^{-6}$ \\
\hline A & 0.804 & 0.0482 & 0.00278 & 0.0169 & 0.00675 \\
\hline B & 0.629 & 0.0828 & 0.0052 & 0.0356 & 0.0166 \\
\hline $\mathrm{C}$ & 0.483 & 0.0433 & 0.00549 & 0.00822 & 0.0272 \\
\hline $\mathrm{D}$ & 0.577 & 0.0873 & 0.00342 & $0.00383^{\mathrm{a}}$ & 0.01950 \\
\hline $\mathrm{E}$ & 0.522 & 0.0342 & 0.00262 & 0.00553 & 0.0134 \\
\hline $\mathrm{F}$ & 0.982 & 0.185 & 0.00421 & $0.0103^{\mathrm{a}}$ & 0.0191 \\
\hline $\mathrm{G}$ & 0.024 & 0.0059 & 0.00451 & 0.0224 & $3.61 \times 10^{-5}$ \\
\hline $\mathrm{H}$ & 0.0506 & 0.00267 & 0.00371 & $9.51 \times 10^{-4 \mathrm{a}}$ & $8.55 \times 10^{-5}$ \\
\hline I & 0.0431 & 0.00369 & 0.00223 & 0.0296 & $1.13 \times 10^{-5}$ \\
\hline
\end{tabular}

Exposure based on assisting person's breathing zone being above a prone victim. Concentrations represent cumulative exposure from $3 \mathrm{~s}$ after the termination of burn for $60 \mathrm{~s}$

${ }^{\text {a }}$ Value not significantly different than controls at $P=0.95$

using conservative IDLH threshold values as measures of threshold toxicity (Figure 9). This was seen with both the 4 and $3 \mathrm{~s}$ fire exposure intervals.

Total acid gas exposure also appears not to represent a significant risk of adverse health impact (Figure 10). Interestingly, a relative equalization was noted as the result of hydrogen chloride and hydrogen cyanide from the modacrylics which were replaced by hydrogen bisulfite/sulfate and nitrogen oxides in the cotton and rayon technologies. This indicates that the risk from acid damage to respiratory membranes was not a significant risk either singularly or in combination.

The combustion gases were found to represent a low risk of adverse respiratory impact in these assessments. There were two reasons observed for this. First, although the rate of gas production was proportional to the amount of heat influx, the period of ventilation was inversely proportional to it. That means that the higher the temperature of the air, the greater the thermal damage to the airway and thus the faster the principal will succumb to involuntary apnea. This 


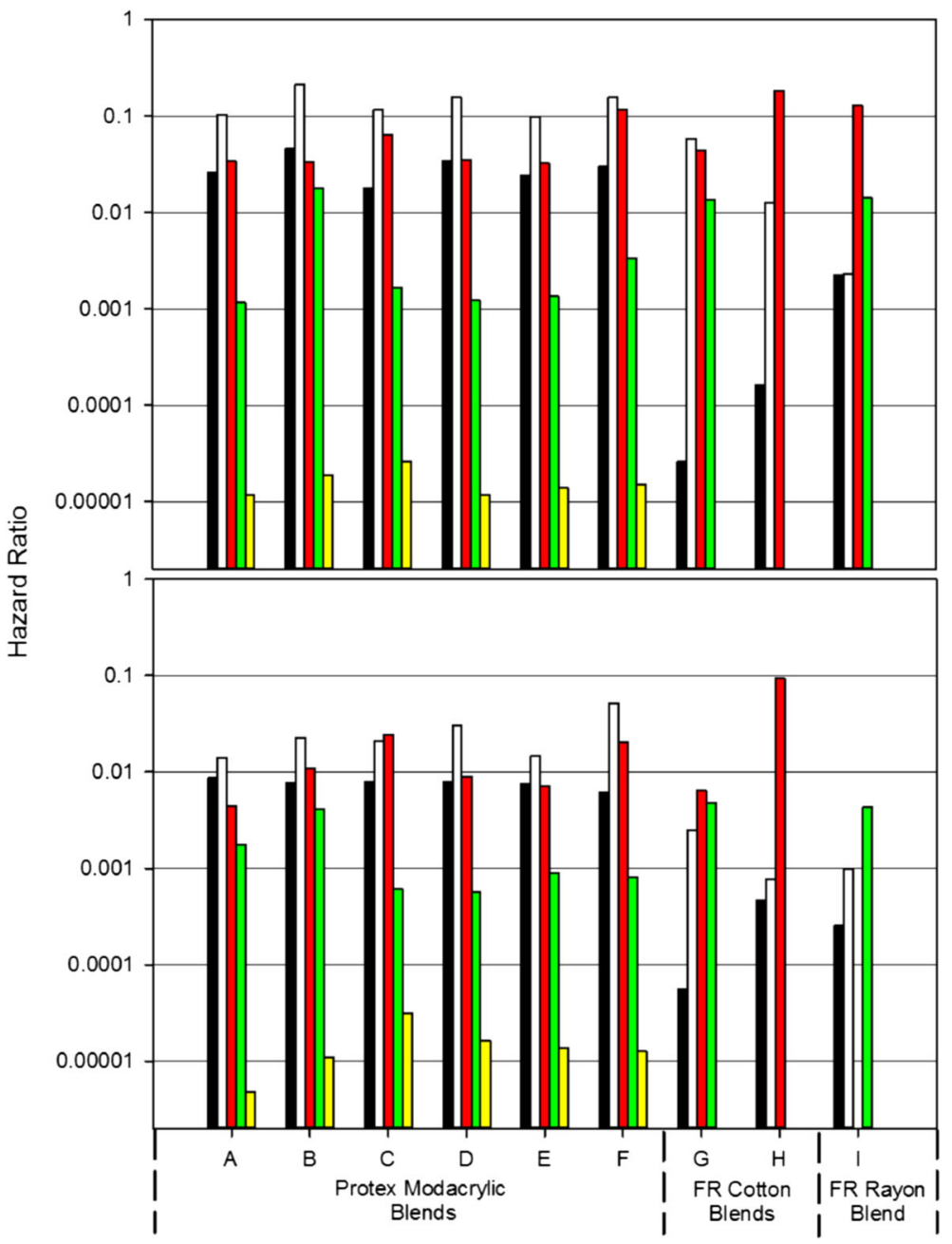

Figure 8. Comparative risk of adverse impact to the principal from combustion gases generated in a flash fire. Bars (in order $L$ to $R$ ) represent the hazard ratio for hydrogen chloride, hydrogen cyanide, nitrogen oxide, sulfur dioxide, and particulate antimony. Values less than 1.0 indicate exposure values less than threshold impact values (Table 5). Results are presented for the $4 \mathrm{~s}$ (top) and $3 \mathrm{~s}$ (botfom) fire exposure times. Absence of bars indicates a hazard ratio less than $1 \times 10^{-6}$.

relation is lost in bench scale bioassay models because the gases are permitted to cool prior to delivery to the receptor $[5,6]$. While results from the bench top bioassays may be useful to determine the risk to third parties present in a confined space with a combustion source, but not impacted by the thermal radiance 


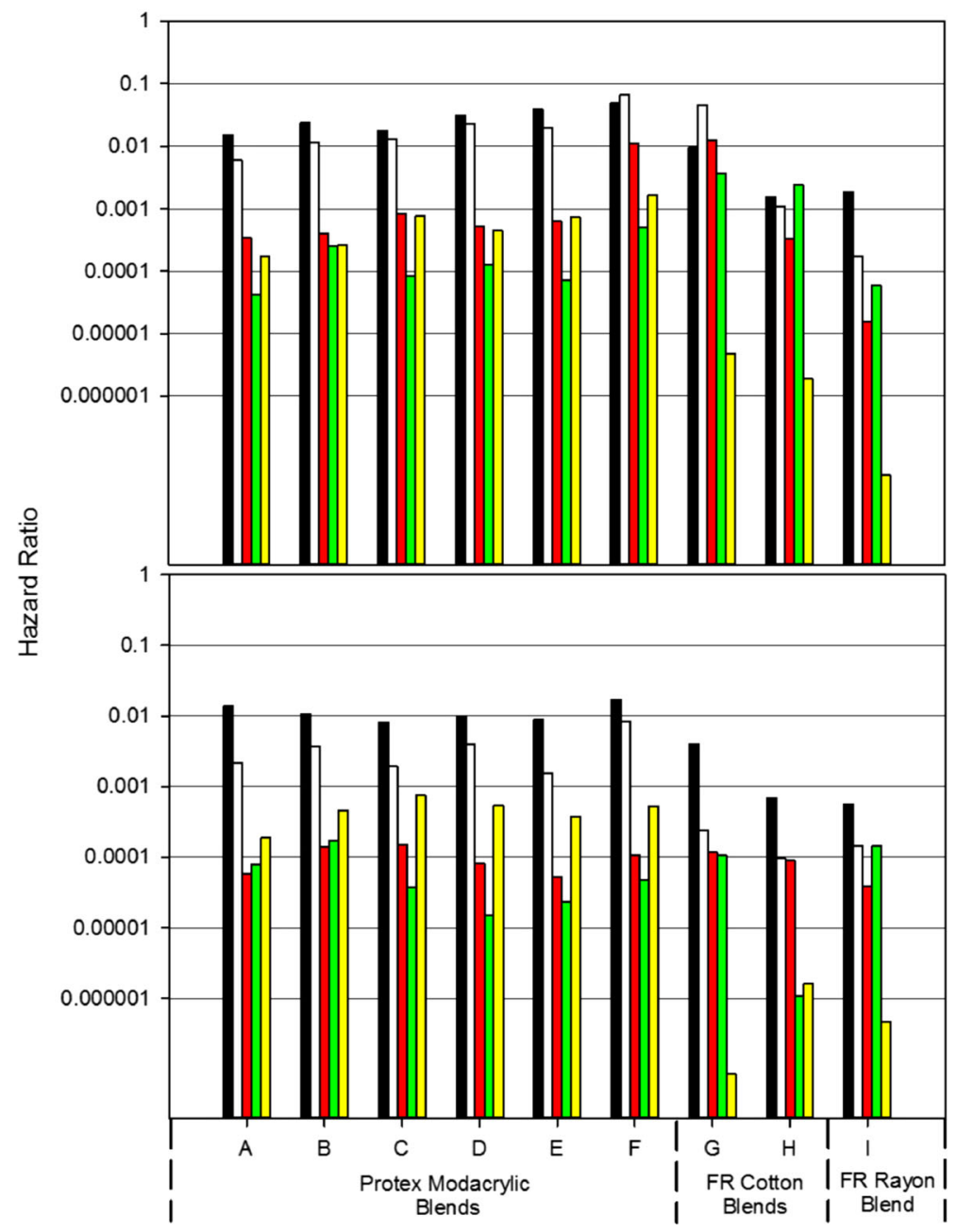

Figure 9. Comparative risk of adverse impact to the third person aid providers from combustion gases generated in a flash fire. Bars (in order L to R) represent the safety windows for hydrogen chloride, hydrogen cyanide, nitrogen oxide, sulfur dioxide, and particulate antimony. Values less than 1.0 indicate 90 s exposure was less than that equivalent to the respective chemicals' threshold of impact. Results are presented for the $4 \mathrm{~s}$ (fop) and $3 \mathrm{~s}$ (botfom) fire exposure times. Absence of bars indicates a hazard ratio less than $1 \times 10^{-7}$.

or heat content of the combustion gases, it does not adequately model exposure from burning apparel to either the principal or the third person aid arriving in an open area after the conclusion of fire exposure.

The second observed reason that the inhalation gases did not present a greater risk is the kinetics of their production. The maximum concentrations of 


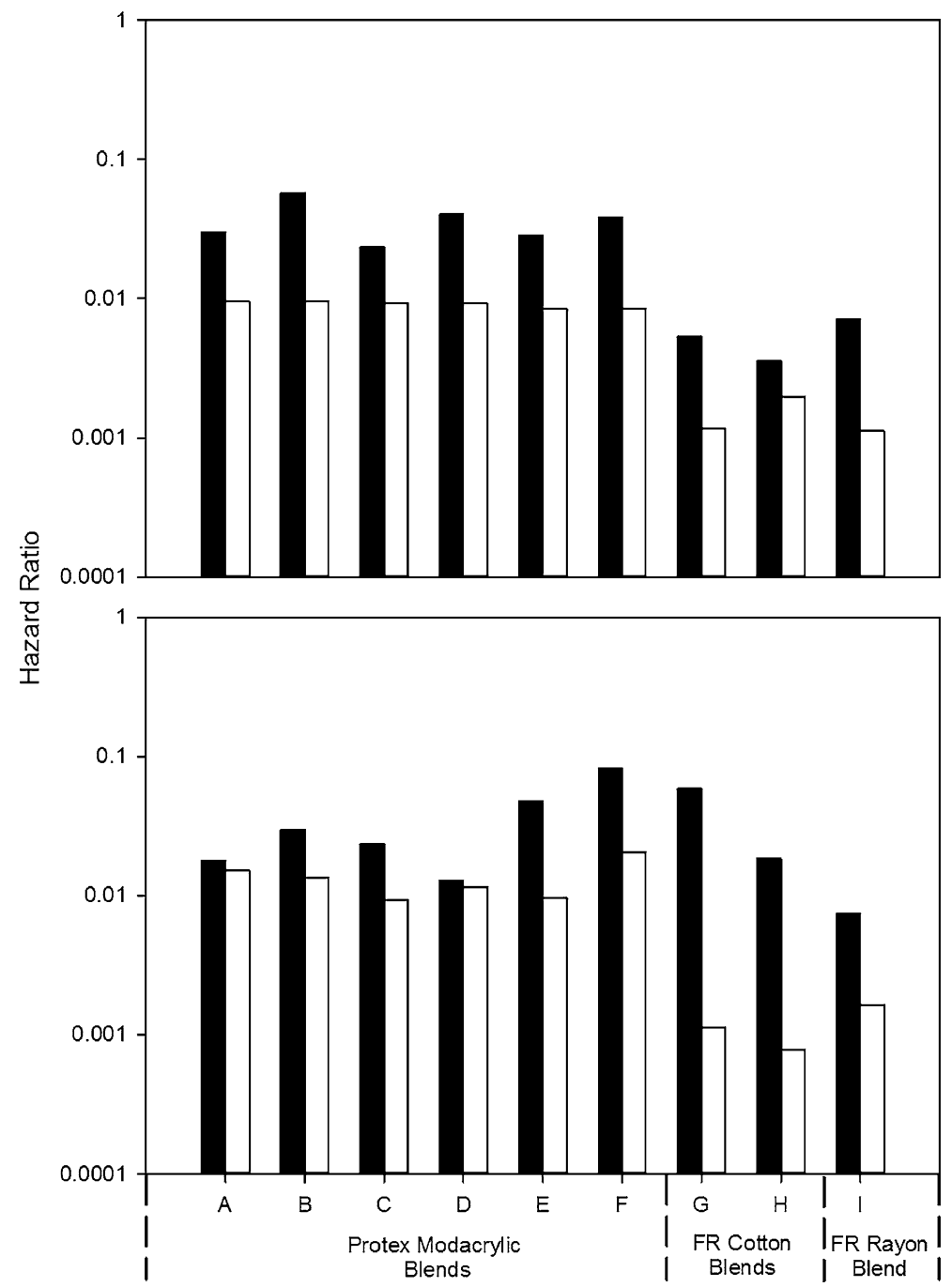

Figure 10. Comparative risk of adverse impact from total acid combustion gases generated in a flash fire for the principal (fop) and the third person aid provider (below) based on $3 \mathrm{~s}$ (open) and $4 \mathrm{~s}$ (solid) exposures. Values less than 1.0 indicates that exposure was less than that equivalent to the respective chemicals' IDLH.

combustion products from the flame-retardant textiles were very high, however the duration of such production was very short. This dramatically limited the available time of exposure before the gases were lost from the breathing zone of the principal. Furthermore, their rapid decline and dissipation after the textiles have stopped burning means that exposures for third party aids are very limited in both time and concentrations of exposure. Our system indicated that gas 
concentrations over background levels could not be detected for any of the monitored gases $60 \mathrm{~s}$ post-ignition. This is believed the reason behind the misleading results attained from mathematically scaling of bench top analyses to whole person exposures [3, 4]. At this scale, the toxicity is not just a function of combustion gas concentration, but also ventilation volume. In the $4 \mathrm{~s}$ burn, total combustion gas concentrations rose from background levels to $25,000 \mathrm{mg} / \mathrm{m}^{3}$ between the first and second breath. Between the second and third breath, the total combustion gas concentrations fell from $25,000 \mathrm{mg} / \mathrm{m}^{3}$ to $1,900 \mathrm{mg} / \mathrm{m}^{3}$. By the end of $1 \mathrm{~min}$, combustion gas concentrations had fallen to less than $3 \mathrm{mg} / \mathrm{m}^{3}$. While this may be an issue in a very confined space for third party aids, it must be remembered that even after $15 \mathrm{~s}$ post-ignition, the emission gas temperatures were at 200 to $300^{\circ} \mathrm{C}$. That means that these gases are highly buoyant and will rise rather than readily mix with ambient air. So for at least the first 1-2 min, the gases will all culminate at the ceiling which is usually well above both the principal's or third person aid's breathing zones.

\section{Conclusions}

Exposure to flash fire conditions is a variable and high risk situation. It constitutes extreme conditions of temperature on a magnitude that will result in severe burns to both the skin and the upper respiratory passages. Survival will depend on the ability of an individual to isolate themselves from the direct heat influx and hot gases.

This assessment indicates that in a general acute flash fire situation in the workplace, the greatest threat to life is third degree respiratory burns to the upper airway (superficial burns to the skin which would also likely be life threatening were not considered in this study). Respiratory and/or systemic effects as the result of exposure to combustion gases through inhalation were found to be the least risk in the occupational scenarios examined. While toxicosis resulting from smoke inhalation is a significant, if not primary hazard associated with established structure fires, it is not the case for short duration workplace engulfment conditions with flame-retardant textiles intended to aid survival and escape of workers. Smoke inhalation is of greatest hazard under long fire exposure scenarios where the receptor is isolated from the combustion but exposed to the cooled gases as may be the case with firefighters exposed to residual combustion gases for long durations. However, the short duration of combustion in the flash fire does not permit for sufficient duration of combustion gas production to represent a significant hazard. In this case, the principal hazard remains burns to the exterior and upper airway as the result of the inhalation of superheated gases.

\section{Open Access}

This article is distributed under the terms of the Creative Commons Attribution License which permits any use, distribution, and reproduction in any medium, provided the original author(s) and the source are credited. 


\section{References}

1. Kallonen R, von Wright A, Tikkenen L, Kaustia K (1985) The toxicity of fire effluents from textiles and upholstery materials. J Fire Sci 3:145-160

2. Cornish HH, Hahn KJ, Barth ML (1975) Experimental toxicology of pyrolysis and combustion hazards. Environ Health Perspec 11:191-196

3. Ackerman MY (2011) Thermal decomposition of selected flame resistant clothing materials. AATCC 11:35-43

4. Bradham A, Thompson D, Barker R, Morton-Aslanis J, Deaton AS (2013) A method for determining off-gassing of protective fabrics exposed to simulated flash fire conditions. AATCC 13:57-65

5. Crane CR, Sanders DC, Endecott BR, Abbott JK, Smith PW (1977) FAA-AM77-9. Federal Aviation Administration, Oklahoma City

6. Birky MM, Paabo M, Levin BC, Womble SE, Malek D (1980) Development of recommended test method for toxicological assessment of inhaled combustion products, NBSIR 80-2077. National Bureau of Standards, Washington

7. DeSesso JM (1993) The relevance to humans of animal models for inhalation studies of cancer in the nose and upper airways. Qual Assur 2:213-231

8. ASTM (2013) Standard F1930: Standard Test Method for Evaluation of Flame Resistant Clothing for Protection Against Fire Simulations Using an Instrumented Manikin. ASTM International, West Conshohocken, PA

9. ISO (2008) Standard 13506: protective clothing against heat and flame-test method for complete garments - prediction of burn injury using an instrumented manikin. International Organization for Standardization, Geneva

10. USEPA (1997) Test method 320: measurement of vapor phase organic and inorganic emissions by extractive Fourier transform infrared (FTIR) spectroscopy. 40CFR 63 App A

11. NIOSH (2003) Method 7303: elements by ICP (hot block $/ \mathrm{HCl} / \mathrm{HNO}_{3}$ digestion). In: Issue 1NIOSH Manual of Analytical Methods (NMAM), 4th edn. National Institute of Occupational Health and Safety, Atlanta

12. Hanna LM, Scherer PW (1986) A theoretical model of localized heat and water vapor transport in the human respiratory tract. ASME J Biomech Eng 108:19-27

13. Lv YG, Lui J, Zang J (2006) Theoretical evaluation of burns to the human respiratory tract due to inhalation of hot gas in the early stage of fires. Burns. 32:436-446

14. Hanna LM, Scherer PW (1986) Measurement of local mass transfer coefficients in a cast model of the human upper respiratory tract. ASME J Biomech Eng 108:12-18

15. Linn WS, Spier CE, Hackney JD (1993) Activity patterns in ozone-exposed construction workers. J. Occ. Med Toxicol. 2:1-14

16. Henriques FC, Moritz AR (1947) Studies of thermal injury I: the conduction of heat to and through skin and the temperatures attained therein. A theoretical and an experimental investigation. Am J Pathol 23:531-549

17. Cataldi P, Nebolsine P, Magill J, Laughlin W, Hinds M (2005) A fabric burn hazard protection evaluation system. In: Proceedings of the 8th International Symposium on Fire Safety Science, pp 837-848

18. Tabulae Biologicae Periodicae. (1933) Tab Biol Per; 3:231

19. CDC (1994) Documentation for immediately dangerous to life or health concentrations (IDLHs): hydrogen chloride. National Institute of Occupational Safety and Health, Washington 
20. CDC (1994) Documentation for immediately dangerous to life or health concentrations (IDLHs): hydrogen cyanide. National Institute of Occupational Safety and Health, Washington DC

21. DECOS (2002) Hydrogen cyanide, sodium cyanide and potassium cyanide. The Hague, Minister and State Secretary of Social Affairs and Employment, Dutch Expert Committee on Occupational Standards

22. WHO (2004) Concise International chemical assessment: hydrogen cyanide and cyanides. Document 61. World Health Organization, Geneva

23. National Research Council (1977) Medical and biological effects of environmental pollutants and nitrogen oxides. National Academy of Sciences, Washington

24. Mayorga MA (1994) Overview of nitrogen dioxide effects on the lung with emphasis on military relevance. Toxicol. 89:175-192

25. AIHA (1955) Sulfur dioxide. In: Hygienic guide series. Am Ind Hyg Assoc Q 16:332333

26. ECHA (2014) Registration dossier for diantimony trioxide $(10,000+$ tonnes per annum). Acute toxicity inhalation.001. http://echa.europa.eu/ja/information-on-chemicals. Last Accessed 1/27/14

27. Bartlett RH, Niccole M, Tavis MJ, Allyn PA, Furnas DW (1976) Acute management of the upper airway in facial burns and smoke inhalation. Arch Surg 111:744-749

28. Miller AJ (2002) Oral and pharyngeal reflexes in the mammalian nervous system: their diverse range in complexity and the pivotal role of the tongue. Crit Rev Oral Biol Med $13: 409-425$

29. Davies AE, Kidd D, Stone SP, MacMahon J (1995) Pharyngeal sensation and gag reflex in healthy subjects. Lancet 345:487-488 